\title{
Beyond Turk and Hindu: Rethinking Religious Identities in Islamic South Asia
}

\author{
David Gilmartin and Bruce B. Lawrence, eds. \\ Gainsville: University Press of Florida, 2000. 354 pages.
}

Beyond Turk and Hindu grew out of a collection of papers presented at a conference on "Islam in South Asia," held at Duke University in April 1995. It has 3 sections, 13 chapters, 8 photographs, 3 maps, 2 tables, a glossary, and an index. The book deals with the broad subject of civilizational interfaces in the South Asian context. It belongs to the category of interfaith relations and is addressed to a general audience interested in the Hindu-Muslim dialectic.

The authors do not accept the premise that interreligious differences in South Asia are set and irreconcilable. To quote the editor: "We vigorously contend that there is a larger point to make, namely, that the constant interplay and overlap between Islamic and Indic worldviews may be at least as pervasive as the Muslim-Hindu conflict ..." This position is a challenge to those scholars who view India and Pakistan as embodiments of two separate religious identities.

Section One contains three essays on textual analysis to assess the sameness and otherness of identity formation. The authors do not avoid the controversies that are bound to emerge from the sometimes disparaging terms used by Hindus and Muslims to refer to each other, or the animosities that have emerged from the desecration of mosques and temples:

Arabic and Persian use of the term Hind $u$ had a range of meanings that changed over time, sometimes denoting an ethnic or geographic referent without religious content. Similarly, Indic texts referring to the invaders from the northwest used a variety of terms in different contexts, including yavanas, mlecchas, farangis, musalmans, and Turks. These terms sometimes carried a strong negative connotation, but they rarely denoted a distinct religious community conceived in opposition to Hindus. In and of themselves, however, such terms tell us little. To understand the usage of these terms, one must move beyond the terminology itself - beyond Turk and Hindu - to analyze the framing categories and generic contexts within which these terms are used.

The authors illustrate the power of bidirectional cultural forces by offering the example of the Punjab's Bulle Shah and Bengal's mystical Satya Pir. Bulle Shah, a contemporary of Shah Waliullah of Delhi, lived in the late 
Mogul period and witnessed the emerging conflict between the Marathas and the Afghans. In the convulsions that rocked the Punjab following Nadir Shah's invasions (1739), Sufism provided a spiritual bridge between the various religious communities. Bulle Shah's haunting melodies, sung in Punjabi, appealed at once to Sufi Muslims and Vasnava Hindus:

Neither Arab am I nor a man of Lahore,

Nor Indian from the town of Nagur,

Neither Hindu am I nor Turk from Peshawar.

To this day, his poems are sung on both sides of the India-Pakistan border in the Punjab. A thousand miles to the east, in the vast province of Bengal, the impact of Sufism produced the mythical figure of Satya Pir (translated as "True Saint" in Bengali). Muslims claim that he is a great Sufi, while Hindus consider him a divine avatar.

A second element that united the two communities was love that transcended ritualistic boundaries. Themes of love run through Sufi songs composed in Farsi, Hindi, Urdu, Punjabi, Bengali, and Tamil. They capture the local context's tensions while remaining true to the larger, universal Islamic paradigm. For instance, Bulle Shah's couplets remind one of Mevlana Rumi's Mathnavi, written some 500 years earlier in Anatolia.

A third element was the emergence of qisas and tazkirat (stories and discourses) in various Indian languages. The Islamic community sought to legitimize its presence in the subcontinent by linking the global to the local through the art forms of qisas and tazkirat using local contexts against a backdrop of a universal Islamic framework.

A fourth element in the composite culture was Indo-Islamic architecture. Using Shahjahanabad and Jaipur as examples, the authors illustrate how the local context produced a rich Indic architecture. Here again, the authors do not shy away from controversies. They document what they claim are temple desecrations and balance it by including the destruction of the Babri Masjid in 1992. However, according to the authors, temple desecration, performed by Muslims and Hindus alike, was not a statement of religious prejudice by Muslim kings or Hindu rajas. Rather, it was an assertion of a new king's authority and a proclamation that the previous dynasty's authority had ended. These observations are a healthy departure from the parochial view held by interested elements, who view mosquetemple disputes in strictly communal terms.

Islam in India was a product of Sufi shaykhs, who were its architects and guardians. Only in recent years has the Sufi color started to fade from 
the South Asian landscape. The essays in Section Two explore in more detail the operation of the Islamic frame of social and intellectual ordering in India. In a composite cultural setting, there is bound to be tension between the universal and the local. Sufism embraced these tensions, molded them to its advantage, and defined the identity of Indo-Muslims in a broader, universal frame. Sufism gave Indian Islam the new art forms of qawwali, gazal (Urdu lyrics), lateefa (subtle stories), and tazkirah.

The essays in Section Three, which deals with state patronage and political order, constitute one of this book's distinguishing features. As Muzaffar Alam's essay "The Shari ah and Governance in the Indo-Islamic Context" points out, deference to the Shari'ah was (and remains) the most visible marker of a ruler's claim to legitimacy in the Islamic world. By the thirteenth century, the Shari ah had taken on a strictly juristic meaning. The society's stability depended on upholding the law as it was interpreted by the ulama.

The thirteenth-century Mongol invasions destroyed the classical Islamic world's political order. Cities like Samarqand, Bukhara, Herat, Kabul, and Isfahan were reduced to ruins. In 1258, Baghdad itself was destroyed. Libraries were burned, the ulama were slaughtered, and the Mongol Rasa replaced the Shari ah as the law of the land. Fresh legal perspectives, acceptable to the Mongol rulers, were required. It was in this milieu that Nasir alDin al-Tusi composed his famous treatise Aqhlakh-e Nasiri. Starting out as a translation of Ibn Miskawah's Tahzib al-Akhlaq, the work grew into a prescription for governance and administration, expanding on the earlier works of al-Farabi and Ibn Sina. It is perhaps the only attempt by a Muslim scholar to bridge the rational and doctrinal in the religio-political space.

The historical Islamic and Indic identities changed in the subcontinent's larger cultural context. Hindu and Muslim identities were constructed through tensions generated by the simultaneous deployment of framing categories of commonality and asserting particularities of difference. The advent of British rule changed the old paradigms and brought in a distinctive structure of colonialism, scientific "rationalism," and capitalism. This framed new identities, coined new definitions of religions as fixed communities susceptible to census-taking, and gave birth to the language of majority and minority. Such categorization tended to legitimate the colonial state's authority and gave the British a new tool in their attempt to divide and rule.

The book's significance lies in its timeliness. At the present moment, when India is rocked by serious communal riots and India and Pakistan square off over Kashmir, many people wonder if the Hindu and Muslim 
communities have been at each other's throats for over a 1,000 years. The answer, fortunately, is no. Hindus and Muslims lived, interacted, and coexisted for centuries before the British arrived. This interaction produced a vibrant Hindustani culture with elements borrowed from Persia, Central Asia, and Vedic India. Only with the arrival of the British in the "modem" period did the emphasis shift from cooperation and coexistence to "democracy" and "communities," "majority" and "minority."

This book's contribution to Islamic thought is to suggest a fresh look at the world's traditional compartmentalization into dar al-Islam and dar alharb. Its weakness, however, lies in its title: Beyond Turk and Hindu. The use of Turk suggests that the subcontinent's Muslims were external invaders, when in fact they belong to the native soil just as much as any other religious community. Its strength is its honest attempt to explore Hindu-Muslim interactions in a traditional matrix, which includes overlapping Islamic and Indic frameworks.

Nazeer Ahmed Former Member of the Legislative Assembly Bangalore, India 